\title{
New Flavonoid Glycosides from the Leaves of Solidago altissima
}

\author{
Bin Wu, ${ }^{a, b}$ Tsukasa Takahashi, ${ }^{a}$ Takehiro Kashiwagi, ${ }^{a}$ Shin-ichi Tebayashi, ${ }^{a}$ and Chul-Sa KIm ${ }^{*}, a$ \\ ${ }^{a}$ Department of Bioresources Science, Faculty of Agriculture, Kochi University; B200 Monobe, Nankoku 783-8502, Japan: \\ and ${ }^{b}$ School of Traditional Chinese Materia Medica, Shenyang Pharmaceutical University; Shenyang 110016, People's \\ Republic of China. Received December 18, 2006; accepted February 9, 2007; published online February 22, 2007
}

Two new flavonoid glycosides kaempferol 3- $O$ - $\beta$-D-apiofuranosyl-(1 $\rightarrow 6)-\beta$-D-glucopyranoside (1), and quercetin 3-O- $\beta$-D-apiofuranosyl-(1 $\rightarrow 6)$ - $\beta$-D-glucopyranoside $(2)$, together with six known flavonoid glycosides were isolated from the leaves of Solidago altissima L. grown in Kochi of Japan. The structure elucidation of the isolated compounds was performed by acid hydrolysis and spectroscopic methods including UV, IR, ESI-MS, 1Dand 2D-NMR experiments.

Key words Solidago altissima; flavonoid glycoside; $1 \mathrm{D}$ NMR; $2 \mathrm{D}$ NMR; kaempferol 3 - $O$ - $\beta$-D-apiofuranosyl-(1 $\rightarrow 6$ )- $\beta$-D-glucopyranoside; quercetin 3-O- $\beta$-D-apiofuranosyl- $(1 \rightarrow 6)-\beta$-D-glucopyranoside

Thrips palmi KARNY (Thysanoptera: Thripidae) is polyphagous pest which has been recorded from 34 plant families but is particularly damaging to Asteraceae, Curcurbitaceae and Solanaceae. ${ }^{1)}$ T. palmi has been distributed worldwide by the trade in plants and plant products and can cause significant economic losses in countries where it establishes. ${ }^{2)}$ In our continuing search for insecticidal substances from common plants against $T$. palmi, two insecticidal constituents were previously reported. ${ }^{3)}$ We recently found out that T. palmi could not attack Solidago altissima L. (Goldenrod: Asteraceae). S. altissima is one of the most common alien plant species in Japan, is native to North America, and is said to have first invaded Japan about a hundred year ago. But it is during these several decades that goldenrod became such a common weed everywhere in Japan. Reports on the chemical constituents of this species have been published and many diterpenoid reported. ${ }^{4)}$ In this report, we described the isolation and structure determination of the constituents from S. altissima.

The methanolic extract of the fresh leaves of $S$. altissima was concentrated and suspended in water and partitioned with solvents of increasing polarity (diethyl ether and $n$-butanol). The $n-\mathrm{BuOH}$ residue was fractionated on column chromatography (RP-MPLC, RP-HPLC) to yield compounds $1-8$.

Compounds $\mathbf{1}$ and $\mathbf{2}$ were obtained as yellow amorphous powders $\left([\alpha]_{\mathrm{D}}^{25}-39.5^{\circ},-67.6^{\circ}\right.$, respectively). On acid hydrolysis of 1, kaempferol, glucose, and apiose (glucose/ apiose, 1/1) were identify by HPLC. From the acid hydrolysate of 2, quercetin, glucose, and apiose (glucose/apiose, 1/1) were identify by HPLC. The high resolution (HR)-ESIMS (positive) of $\mathbf{1}$ and $\mathbf{2}$ gave the quasimolecular ions [M+ $\mathrm{H}^{+}$at $\mathrm{m} / \mathrm{z} 581.1479$ (Calcd 581.1501) and 597.1473 (Calcd $597.1450)$, indicating the molecular formulas of $\mathrm{C}_{26} \mathrm{H}_{28} \mathrm{O}_{15}$ and $\mathrm{C}_{26} \mathrm{H}_{28} \mathrm{O}_{16}$, respectively. The molecular ion of $\mathbf{1}$ was 16 mass units smaller than that of 2 , which corresponds to the difference in the number of hydroxyl group on the B ring of the flavonol aglycone.

The ${ }^{1} \mathrm{H}-\mathrm{NMR}$ spectrum in DMSO- $d_{6}$ of 1 showed signals for kaempferol: $\delta 6.19(1 \mathrm{H}, \mathrm{d}, J=2.0 \mathrm{~Hz}, \mathrm{H}-6), 6.41(1 \mathrm{H}, \mathrm{d}$, $J=2.0 \mathrm{~Hz}, \mathrm{H}-8), 6.88\left(2 \mathrm{H}, \mathrm{d}, J=8.8 \mathrm{~Hz}, \mathrm{H}-3^{\prime},-5^{\prime}\right)$, and 8.00 $\left(2 \mathrm{H}, \mathrm{d}, J=8.8 \mathrm{~Hz}, \mathrm{H}-2^{\prime},-6^{\prime}\right)$ and anomeric protons at $\delta 5.38$ $(1 \mathrm{H}, \mathrm{d}, J=7.2 \mathrm{~Hz})$ and $4.69(1 \mathrm{H}, \mathrm{d}, J=2.5 \mathrm{~Hz})$ characteristic of glucose and apiose, respectively (Table 1). The ${ }^{1} \mathrm{H}-\mathrm{NMR}$ of 2 in DMSO- $d_{6}$ revealed the presence of quercetin: $\delta 6.17$ $(1 \mathrm{H}, \mathrm{d}, J=2.0 \mathrm{~Hz}, \mathrm{H}-6), 6.36(1 \mathrm{H}, \mathrm{d}, J=2.0 \mathrm{~Hz}, \mathrm{H}-8), 6.83$ $\left(1 \mathrm{H}, \mathrm{d}, J=8.8 \mathrm{~Hz}, \mathrm{H}-5^{\prime}\right), 7.53\left(1 \mathrm{H}, \mathrm{d}, J=1.6 \mathrm{~Hz}, \mathrm{H}-2^{\prime}\right)$, and $7.53\left(1 \mathrm{H}, \mathrm{d}, J=1.6,8.8 \mathrm{~Hz}, \mathrm{H}-6^{\prime}\right)$ and similar anomeric protons to those in 1. From the coupling constants of the anomeric protons on $\mathbf{1}$ and $\mathbf{2}$, the configurations at $\mathrm{C}-1$ of the glucose and apiose were determined to be the $\beta$-configuration. The apiosyl terminal sugar was shown to be linked to glucose through a $1 \rightarrow 6$ bond for both 1 and 2 on the basis of the glucosyl C-6 downfield shift of 6.5 and $6.3 \mathrm{ppm}$ at $\delta$ $67.3 \mathrm{ppm}$ for 1 and at $\delta 67.2 \mathrm{ppm}$ for 2 , corresponding to the known compounds 3 and 4, respectively. The HMBC spectra, showing cross-peaks of the apiosyl H-1 ( $\delta 4.69,4.39)$ with the glucosyl C- 6 , confirmed the $1 \rightarrow 6$ linkage between these two sugar moieties. The ${ }^{13} \mathrm{C}$-NMR spectra of $\mathbf{1}$ and $\mathbf{2}$ were very similar, except for the signals corresponding to the flavonol aglycone (Table 1). The complete assignment of all protons and carbons were established by extensive use and interpretation of ${ }^{1} \mathrm{H}-{ }^{1} \mathrm{H}$ COSY, HMQC, and $\mathrm{HMBC}$ spectra. In the HMBC spectra, the glucosyl H-1 was correlated with the aglycone $\mathrm{C}-3$, respectively. Considering all the data, the structures of $\mathbf{1}$ and $\mathbf{2}$ were determined to be the 3-O- $\beta$ D-apiofuranosyl- $(1 \rightarrow 6)-\beta$-D-glucopyranoside of kaempferol and quercetin, respectively. In addition, kaemferol 3-O-

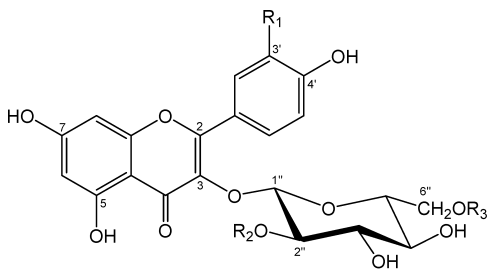

$\begin{array}{lccc} & \mathbf{R}_{\mathbf{1}} & \mathbf{R}_{\mathbf{2}} & \mathbf{R}_{\mathbf{3}} \\ \mathbf{1} & \mathrm{H} & \mathrm{H} & \text { Api } \\ \mathbf{2} & \text { OH } & \text { H } & \text { Api } \\ \mathbf{3} & \text { H } & \text { H } & \text { H } \\ \mathbf{4} & \text { OH } & \text { H } & \text { H } \\ \mathbf{5} & \text { H } & \text { H } & \text { Rha } \\ \mathbf{6} & \text { OH } & \text { H } & \text { Rha } \\ \mathbf{7} & \text { H } & \text { Api } & \text { H } \\ \mathbf{8} & \text { H } & \text { Api } & \text { Rha }\end{array}$

Fig. 1. Structures of Flavonoid Glycosides $\mathbf{1}-\mathbf{8}$ 
Table 1. NMR Data for Compounds $\mathbf{1}$ and 2 in DMSO- $\left.d_{6}{ }^{a, b}\right)$

\begin{tabular}{|c|c|c|c|c|}
\hline \multirow{2}{*}{ Position } & \multicolumn{2}{|l|}{1} & \multicolumn{2}{|l|}{2} \\
\hline & $\delta_{\mathrm{H}} J(\mathrm{~Hz})$ & $\delta_{\mathrm{C}}$ & $\delta_{\mathrm{H}} J(\mathrm{~Hz})$ & $\delta_{\mathrm{C}}$ \\
\hline $2^{c)}$ & & $156.4(\mathrm{~s})$ & & $156.3(\mathrm{~s})$ \\
\hline 3 & & $133.1(\mathrm{~s})$ & & $133.3(\mathrm{~s})$ \\
\hline 4 & & $177.2(\mathrm{~s})$ & & $177.2(\mathrm{~s})$ \\
\hline 5 & & $161.1(\mathrm{~s})$ & & $160.8(\mathrm{~s})$ \\
\hline 6 & $6.19 \mathrm{~d}(2.0)$ & 98.8 (d) & $6.17 \mathrm{~d}(2.0)$ & $98.8(d)$ \\
\hline 7 & & $164.3(\mathrm{~s})$ & & $163.9(\mathrm{~s})$ \\
\hline 8 & $6.41 \mathrm{~d}(2.0)$ & 93.7 (d) & $6.36 \mathrm{~d}(2.0)$ & $93.7(d)$ \\
\hline $9^{c)}$ & & $156.5(\mathrm{~s})$ & & $156.2(\mathrm{~s})$ \\
\hline 10 & & $103.9(\mathrm{~s})$ & & $103.6(\mathrm{~s})$ \\
\hline $1^{\prime}$ & & $120.9(\mathrm{~s})$ & & $121.0(\mathrm{~s})$ \\
\hline $2^{\prime}$ & $8.00 \mathrm{~d}(8.8)$ & $130.8(d)$ & $7.53 \mathrm{~d}(1.6)$ & 114.9 (d) \\
\hline $3^{\prime}$ & $6.88 \mathrm{~d}(8.8)$ & $115.1(\mathrm{~d})$ & & $144.7(\mathrm{~s})$ \\
\hline $4^{\prime}$ & & $159.8(\mathrm{~s})$ & & $148.6(\mathrm{~s})$ \\
\hline $5^{\prime}$ & $6.88 \mathrm{~d}(8.8)$ & $115.1(\mathrm{~d})$ & $6.83 \mathrm{~d}(8.8)$ & 116.3 (d) \\
\hline $6^{\prime}$ & $8.00 \mathrm{~d}(8.8)$ & $130.8(d)$ & $7.53 \mathrm{dd}(1.6,8.8)$ & $121.4(\mathrm{~d})$ \\
\hline Glc-1 & $5.38 \mathrm{~d}(7.2)$ & $100.9(\mathrm{~d})$ & $5.32 \mathrm{~d}(7.6)$ & $100.9(d)$ \\
\hline 2 & $3.19 \mathrm{~m}$ & $74.2(\mathrm{~d})$ & $3.27 \mathrm{~m}$ & $74.4(d)$ \\
\hline 3 & $3.22 \mathrm{~m}$ & $75.8(d)$ & $3.30 \mathrm{~m}$ & $75.7(d)$ \\
\hline 4 & $3.06 \mathrm{t}(8.8)$ & $69.9(d)$ & $3.14 \mathrm{~m}$ & $70.2(d)$ \\
\hline 5 & $3.25 \mathrm{~m}$ & 75.9 (d) & $3.30 \mathrm{~m}$ & $75.9(d)$ \\
\hline \multirow[t]{2}{*}{6} & 3.69 brd (11) & $67.3(\mathrm{t})$ & $3.69 \mathrm{~d}(12.0)$ & $67.2(\mathrm{t})$ \\
\hline & $3.33 \mathrm{dd}(6,11)$ & & $3.48 \mathrm{~d}(12.0)$ & \\
\hline Api-1 & $4.69 \mathrm{~d}(2.5)$ & $109.2(d)$ & $4.39 \mathrm{~d}(1.2)$ & 109.7 (d) \\
\hline 2 & $3.78 \mathrm{~d}(2.5)$ & 76.4 (d) & $3.92 \mathrm{~d}(2.0)$ & $76.2(d)$ \\
\hline 3 & & $78.7(\mathrm{~s})$ & & $78.4(\mathrm{~s})$ \\
\hline \multirow[t]{2}{*}{4} & $3.62 \mathrm{~d}(9.5)$ & $73.2(\mathrm{t})$ & $3.82 \mathrm{~d}(10)$ & $73.1(\mathrm{t})$ \\
\hline & $3.45 \mathrm{~d}(9.5)$ & & $3.55 \mathrm{~d}(10)$ & \\
\hline 5 & $3.18 \mathrm{~s}$ & $63.5(\mathrm{t})$ & $3.31 \mathrm{~s}$ & $63.8(\mathrm{t})$ \\
\hline
\end{tabular}

a) The chemical shifts (in ppm) were reported relative to the solvent signal $\left({ }^{1} \mathrm{H}\right.$ NMR; $\left.2.49 \mathrm{ppm},{ }^{13} \mathrm{C}-\mathrm{NMR} ; 39.5 \mathrm{ppm}\right)$. b) Chemical shifts based on ${ }^{1} \mathrm{H}-{ }^{1} \mathrm{H}$ COSY, HMQC and HMBC data. c) Assignments may be interchanged.

$\beta$-D-glucopyranoside (=astragalin) (3), ${ }^{5)}$ quercetin $3-O-\beta$-Dglucopyranoside (=isoquercitrin) (4), ${ }^{6}$ kaempferol 3-O$\alpha$-L-rhamnopyranosyl- $(1 \rightarrow 6)-\beta$-D-glucopyranoside (=nicotiflorin) (5), ${ }^{7}$ quercetin 3-O- $\alpha$-L-rhamnopyranosyl- $(1 \rightarrow 6)-\beta$ D-glucopyranoside (=rutin) (6), ${ }^{7)}$ kaempferol 3- $O-\beta$-D-apiofuranosyl- $(1 \rightarrow 2)$ - $\beta$-D-glucopyranoside $(7),{ }^{7}$ and kaempferol 3 - $O$ - $\beta$-D-apiofuranosyl- $(1 \rightarrow 2)-O$ - $[\alpha$-L-rhamnopyranosyl$(1 \rightarrow 6)]$ - $\beta$-D-glucopyranoside $(\mathbf{8}){ }^{8)}$, were also identified by comparison of their physical and spectral data with those reported in the literature. Of these known compounds, 7 and 8 were first found from Solidago genus and $\mathbf{4}$ was reported from this plant for the first time. When adults of T. palmi were allowed to feed the crude methanol extract of the leaves of $S$. altissima, the insects were died within $7 \mathrm{~d}$ (The bioassay method was conducted according to ref. 3.). This result seems to be not based on insecticidal activity, but antifeeding activity against this insect species. In the near future, we will report the antifeeding activity of these flavonoids against $T$. palmi.

\section{Experimental}

General Optical rotations were measured on a Horiba SEPA-200 high sensitive polarimeter. UV and FT-IR spectra were recorded on Shimadzu UV-2550 UV-visible spectrophotometer and Shimadzu FTIR-8400s IR prestige-21, respectively. ${ }^{1} \mathrm{H}$ - and ${ }^{13} \mathrm{C}-\mathrm{NMR}$ spectra were recorded on a JEOL JNN-L400 instrument $\left(400 \mathrm{MHz}\right.$ for ${ }^{1} \mathrm{H}$ and $100 \mathrm{MHz}$ for $\left.{ }^{13} \mathrm{C}\right)$ at $30{ }^{\circ} \mathrm{C}$, and DMSO- $d_{6}$ was used for solvent. Chemical shifts were based on those of the solvent signals $\left(\delta_{\mathrm{H}} 2.49\right.$ and $\delta_{\mathrm{C}} 39.5$ for DMSO- $\left.d_{6}\right)$. Multiplicities of ${ }^{13} \mathrm{C}$ resonances were determined by DEPT $135,{ }^{1} \mathrm{H}-{ }^{1} \mathrm{H}$ COSY, HMQC, and HMBC spectra were performed using software JEOL AL for Windows 98 version 4.0. The positive ion ESI-MS and HR-ESI-MS spectra were obtained on a Shimadzu 2010 LC-MS and Finnigan LCQ. MPLC was performed using Chromatorex ${ }^{\circledR}$ ODS (100-200 mesh, Fuji Silysia Chemical Ltd.) and a preparative Ultra Pack ODS-S-50C (37 i.d. $\times 300 \mathrm{~mm}, 120 \AA$, Yamazen Corporation) column on a Yamazen 600A pump (UV-detector PREP-UV254 and FR50N fraction collector). Preparative HPLC was performed using Cosmosil Packed Column for HPLC 5Ph Waters column (10 i.d. $\times 250 \mathrm{~mm}, 5 \mu \mathrm{m}$ ) on a Shimadzu LC-6AD liquid chromatograph consisting of SCL-10Avp system controller, SPD-M10Avp diode array detector, CTO-10Avp column oven, SIL-10ADvp auto injector, and FRC-10A fraction collector

Plant Material Leaves of S. altissima L. were collected on the banks of the Monobe river, Nankoku city of Kochi, Japan in October 2005.

Extraction and Isolation The fresh leaves of S. altissima $(5.5 \mathrm{~kg})$ were extracted two times with $\mathrm{MeOH}$ at room temperature for $5 \mathrm{~d}$ under darkness. The $\mathrm{MeOH}$ extract $(382 \mathrm{~g}$ ) was suspended in water and partitioned with diethyl ether $(1.21 \times 2)$ and water-saturated $n$-butanol $(1.21 \times 2,187 \mathrm{~g})$ and the aqueous layer $(157 \mathrm{~g})$, successively. A portion of the $n$-butanol fraction $(34 \mathrm{~g})$ was applied to Chromatorex ${ }^{\circledR}$ ODS (485 g) MPLC (water $\rightarrow 40 \%$ $\mathrm{MeOH} \rightarrow 80 \% \mathrm{MeOH} \rightarrow 100 \% \mathrm{MeOH}, 41$ of each) to yield four fractions. The fraction eluted with $40 \% \mathrm{MeOH}(6.9 \mathrm{~g})$ was chromatographed on a preparative Ultra Pack ODS-S-50C column with $30 \% \mathrm{MeOH}, 40 \% \mathrm{MeOH}$, and $\mathrm{MeOH}$ ( 21 of each). The $40 \% \mathrm{MeOH}$ eluate subfraction was separated by RP-HPLC [Cosmosil Packed Column for HPLC 5Ph Waters column, $17 \% \mathrm{MeCN}, 3 \mathrm{ml} / \mathrm{min}$ ] to obtain $1\left(23.5 \mathrm{mg}, t_{\mathrm{R}}=28.4 \mathrm{~min}\right), 2(35.2 \mathrm{mg}$, $\left.t_{\mathrm{R}}=19.7 \mathrm{~min}\right), \quad 3 \quad\left(17.1 \mathrm{mg}, t_{\mathrm{R}}=38.6 \mathrm{~min}\right), 4\left(12.3 \mathrm{mg}, t_{\mathrm{R}}=23.6 \mathrm{~min}\right), \mathbf{5}$ $\left(64.8 \mathrm{mg}, \quad t_{\mathrm{R}}=32.7 \mathrm{~min}\right), \quad 6 \quad\left(21.5 \mathrm{mg}, t_{\mathrm{R}}=21.5 \mathrm{~min}\right), \quad 7 \quad\left(13.0 \mathrm{mg}, t_{\mathrm{R}}=\right.$ $26.4 \mathrm{~min})$, and $8\left(18.3 \mathrm{mg}, t_{\mathrm{R}}=17.7 \mathrm{~min}\right)$.

Kaempferol 3- $O$ - $\beta$-D-apiofuranosyl-( $1 \rightarrow 6)-\beta$-D-glucopyranoside (1): Yellow amorphous powder, $[\alpha]_{\mathrm{D}}^{25}-39.5^{\circ}(c=0.1, \mathrm{MeOH})$. UV (MeOH) $\lambda_{\max }$ : $262,300 \mathrm{sh}, 350 \mathrm{~nm}$. ESI-MS $m / z: 581[\mathrm{M}+\mathrm{H}]^{+}, 449[\mathrm{M}+\mathrm{H}-\mathrm{Api}]^{+}, 287$ $[\mathrm{M}+\mathrm{H}-\mathrm{Api}-\mathrm{Glc}]^{+}$. HR-ESI-MS $\mathrm{m} / z$ : $581.1479[\mathrm{M}+\mathrm{H}]^{+}$(Calcd for $\left.\mathrm{C}_{26} \mathrm{H}_{29} \mathrm{O}_{15}: 581.1501\right) .{ }^{1} \mathrm{H}$ - and ${ }^{13} \mathrm{C}-\mathrm{NMR}$ data see Table 1.

Quercetin 3- $O-\beta$-D-apiofuranosyl-( $1 \rightarrow 6)$ - $\beta$-D-glucopyranoside (2): Yellow amorphous powder, $[\alpha]_{\mathrm{D}}^{25}-67.6^{\circ}(c=0.11, \mathrm{MeOH})$. UV (MeOH) $\lambda_{\max }: 254$, 263, $300 \mathrm{sh}, 353 \mathrm{~nm}$. ESI-MS $m / z: 597[\mathrm{M}+\mathrm{H}]^{+}, 465[\mathrm{M}+\mathrm{H}-\mathrm{Api}]^{+}, 303$ $[\mathrm{M}+\mathrm{H}-\mathrm{Api}-\mathrm{Glc}]^{+}$. HR-ESI-MS $m / z: 597.1473 \quad[\mathrm{M}+\mathrm{H}]^{+}$(Calcd for $\left.\mathrm{C}_{26} \mathrm{H}_{29} \mathrm{O}_{16}: 597.1450\right) .{ }^{1} \mathrm{H}$ - and ${ }^{13} \mathrm{C}-\mathrm{NMR}$ data see Table 1.

Acid Hydrolysis $1 \%$ Aqueous $\mathrm{HCl}(1 \mathrm{ml})$ was added to portion of each isolated compound $(5 \mathrm{mg})$, and the resulting solution in a sealed ampoul was heated on a water bath at $80^{\circ} \mathrm{C}$ for $120 \mathrm{~min}$. The solution was diluted with $\mathrm{H}_{2} \mathrm{O}(2 \mathrm{ml})$, passed through a BondElut ${ }^{\mathbb{R}} \mathrm{JR}^{-\mathrm{C}_{18}}$ (Varian), and rinsed with $\mathrm{H}_{2} \mathrm{O}(2 \mathrm{ml})$. The water eluate was collected and submitted to HPLC analysis of the sugars. A further eluate with $\mathrm{MeOH}(5 \mathrm{ml})$ was collected and submitted to HPLC analysis of the flavonoid aglycones. The HPLC conditions for the sugar analyses were: solvent, $75 \% \mathrm{MeCN}$; column, Capcell Pak $\mathrm{NH}_{2}$ $120 \AA$ (4.6 i.d. $\times 250 \mathrm{~mm}$, Shiseido); detector, Shimadzu RID-10A; flow rate, $1.0 \mathrm{ml} / \mathrm{min}$; temp., $30^{\circ} \mathrm{C}$. The HPLC conditions for the aglycone analyses were: solvent, $18 \% \mathrm{MeCN}$; column, Capcell Pak $\mathrm{C}_{18}$ SG $120 \AA$ (4.6 i.d. $\times 250 \mathrm{~mm}$, Shiseido); flow rate, $0.8 \mathrm{ml} / \mathrm{min}$; temp., $30^{\circ} \mathrm{C}$.

\section{References}

1) Miyazaki M., Kudo I., "Bibliography and Host Plant Catalogue of Thysanoptera of Japan," Vol. 3, Publication of the Natural Institue of Agro-Environmental Science, Tsukuba, 1988, pp. 1-246.

2) Kirk D. J., Terry L. I., Agric. Forest Entomol., 5, 301-310 (2003).

3) Kim C. S., Hara T., Datta P. K., Itoh E., Horiike M., Biosci. Biotechnol. Biochem., 62, 1546-1549 (1998).

4) Merritt A. T., Ley S. V., Nat. Prod. Rep., 9, 243-287 (1992).

5) Agarwal P. K., "Carbon-13 NMR of Flavonoids," Elsevier Science Publishers B.V., Amsterdam, 1989, pp. 303, 334-335.

6) Agarwal P. K., "Carbon-13 NMR of Flavonoids," Elsevier Science Publishers B.V., Amsterdam, 1989, pp. 304, 336-337.

7) Agarwal P. K., "Carbon-13 NMR of Flavonoids," Elsevier Science Publishers B.V., Amsterdam, 1989, pp. 306, 340-342.

8) Piccinelli A. L., Veneziano A., Passi S., Simone F. D., Rastrelli L., Food Chem., 100, 344-349 (2007). 